\title{
Environmental justice and corporate social irresponsibility: the case of the mining company Vale S.A
}

\author{
Beatriz Macchione Saes \\ Daniela Del Bene \\ Raquel Neyra \\ Lucrecia Wagner \\ Joan Martínez-Alier
}

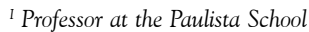
of Politics, Economics and Business at the Federal University of São Paulo (Unifesp), Osasco, SP, Brasil.

"II Post-Doc researcher at the Institute of Environmental Science and Technology of the Autonomous University of Barcelona (UAB), Catalunya, Spain.

III Professor in the Doctorate of Natural Resource Economics and Sustainable Development, Universidad Nacional Agraria La Molina, Lima, Peru.

D IV Researcher at Instituto Argentino de Nivología, Glaciología y Ciencias Ambientales, National Council for Scientific and Technical Investigations (CONICET), Mendoza, Argentina.

$\checkmark$ Professor Emeritus at the Institute of Environmental Science and Technology (ICTA) of the Autonomous University of Barcelona, Catalunya, Spain.
Abstract: After the Vale's tailings dam failure in Brumadinho (Minas Gerais) in early 2019, a group of researchers and activists from around the world produced a thematic map in the Global Atlas of Environmental Justice (EJAtlas) including 30 cases of environmental conflicts in which Vale had a prominent role. In this paper, these cases are analysed in light of Vale's corporate social responsibility (CSR) discourses and practices, aiming to explore the contradiction of high CSR standards in the company and in other large multinationals in the mining sector coexisting with many socio-environmental conflicts. The analysis indicates that the company's performance contrasts with its CSR discourse and that, even when Vale considers its performance both responsible and exemplary, the company reproduces environmental injustices and is therefore rather practicing Corporate Social Irresponsibility.

Keywords: Environmental Justice, Corporate Social Irresponsibility, Mining.

São Paulo. Vol. 24, 2021

Debating Ideas

Decolonial Insurgences and Emancipatory Horizons: Contributions of Political Ecology

DOI: http://dx.doi.org/10.1590/1809-4422asoc20210014vu2021L4ID 


\section{Introduction}

In recent years, the social irresponsibility of the mining company Vale SA (hereafter, Vale) has become globally recognized after the failure of two major mining tailings dams in the towns of Mariana and Brumadinho, located in the mining region of the state of Minas Gerais, Brazil. The failures, which occurred respectively in late 2015 and early 2019 , are among the greatest tragedies in the history of global mining, both concerning the extent of environmental, social, and health impacts and for having caused almost 300 deaths (ROCHE et al., 2017). The company had already been involved in conflictual cases involving socio-environmental issues both within Brazil ${ }^{1}$ and around the world. As part of the Global Atlas of Environmental Justice (hereafter, EJAtlas) project, after the rupture of the Brumadinho tailings dam in 2019, a group of researchers and activists from around the world produced a thematic map that includes 30 cases of environmental conflicts in which Vale had a prominent role. This paper shows the social and political relevance of this kind of map in shedding light on environmental injustices produced by large corporations. This corporation's disproportionate power in relation to other actors may prevent due accountability for the injustices imposed and we hope that mapping their activities will contribute to rebalancing power dynamics.

Environmental justice (EJ) is a concept that links environmental problems to social justice. It refers to the disproportionate imposition of environmental risks on populations that have less financial, political and informational resources (ACSELRAD et al., 2009; MARTÍNEZ-ALIER, 2002).The concept, emerged in the 1980s in the United States, in the context of struggles against the uneven distribution of environmental costs and benefits among different social groups (BULLARD, 1994), has evolved in both academic and activist environments in other geographical and social context, including in the Latin American continent such as in Brazil (PORTO; FINAMORE, 2012; WAGNER, 2020).

The EJAtlas documents and catalogs EJ conflicts around the world, contributing to the mapping, study and visibility of injustices caused by economic activities related to resource extraction, transportation or waste disposal (TEMPER et al., 2015; 2018). It is coordinated by the research group on ecological economics and political ecology at the Institute of Environmental Science and Technology of the Autonomous University of Barcelona, under the direction of Joan Martínez-Alier and Leah Temper and coordination of Daniela Del Bene. The expansion of records involves the participation of researchers, environmental movements, students and activists from around the world. In many cases, the registered information shows environmental injustices caused by well-known corporations, such as Chevron (ejatlas.org/featured/chevronconflicts) and Pan American Silver (ejatlas.org/featured/envconflictspas). These maps indicate that the EJAtlas, in addition to contributing to the studies of environmental social sciences, can also be relevant for research related to business economics and the study of organizations - notably, for those focused on corporate social responsibility (CSR) and corporate social irresponsibility (CSIR) (AMSTRONG, 1997; RIERA; IBORRA, 2017). 
The concept of CSR has become popular since the 1950s as a means of holding transnational corporations accountable for their behaviour (CARROLL, 1999; GARRIGA; MELÉ, 2004). However, recent academic literature criticizes CSR frameworks for being weak in addressing dimensions of sustainability (CHO; PATTEN, 2013; MAHER, 2019), while activist groups criticize the application of CSR measures by corporations themselves as merely being an additional tool for profit. The concept of CSIR stems from this critical view, suggesting that non-critical CSR may make it easier for corporations to perform even more "socially irresponsible" acts (RIERA; IBORRA, 2017). This paper contributes to the literature on CSIR by taking into account grievances and claims from the communities affected by Vale. It intends to highlight the corporate activities and practices that produce environmental injustices as well as the social mobilizations and resistance, all of which stand in flagrant contrast with Vale's corporate narrative of responsibility.

The paper is structured as follows: section 2 discusses how CSR was incorporated by the mining sector and Vale. Section 3 presents the methods for documenting conflicts, building the thematic map in the EJAtlas and analyzing the cases. In Section 4, we describe the main characteristics of the catalogued conflicts and investigate the coexistence of CSR and CSIR practices at Vale. Finally, we present the conclusions.

\section{Context}

\subsection{CSR in mining}

The adoption of CSR practices in corporate businesses underwent a significant boost in recent decades. In a context of strengthening neoliberalism, private and voluntary regulation mechanisms found fertile ground to replace other forms of regulation, including in social and environmental spheres that were, until then, predominantly the responsibility of the State (HIMLEY, 2010). Multinational corporations, in as much as they concentrated great economic and political power, had an outstanding role in leading the adoption of these initiatives. These corporations responded internally to the social pressures related to their performance, discarding the need for new legal apparatuses that would overcome limitations posed by the absence of a transnational regulatory regime (SHAMIR, 2004; BANERJEE, 2008).

In the mining sector, an additional element leading to the discussion of CSR by large corporations in the late 1990s was the sector's notable poor social and environmental reputation. First, to make mining expansion and the development of enterprises feasible, mining companies needed to face the growing resistance of local communities to their projects, which were increasingly perceived as negative due to the socio-environmental impacts and events such as dam breaks, chemical spills and conflicts with communities (JENKINS, 2004). The term "social license to operate", referring to the acceptance of mining projects by communities, was used by the sector itself as a strategic factor in the management of these projects (PRNO; SLOCOMBE, 2012; PARSONS et al., 2014). To regain legitimacy and credibility among communities, companies introduced communication policies and community intervention plans. They also acted through dedicated 
foundations, taking advantage of the lack of investments by local public authorities to promote the idea that mining-spurred community development is beneficial and sustainable (ANTONELLI, 2009).

Second, the financing conditions for these projects would not prove to be very prosperous until the negative social perception of mining was changed. In the late 1990s, large mining companies also sought to expand their participation in the financial markets, where other sectors had a much more successful performance. Therefore, it was necessary to improve the sector's image in the eyes of potential investors, who saw socioenvironmental impacts as potential risks to business (HUMPHREYS, 2015).

During the 1999 World Economic Forum, large multinational mining companies created the International Council on Mining and Metals (ICMM), which defines principles and guidelines for good practices to be followed by participating mining companies and associations. Mining has since become a very active sector in CSR practices. The largest mining companies became signatories to the ICMM and started to prepare sustainability reports, based on the methodology of the Global Reporting Initiative (GRI) (BÖHLING et al., 2017). This global articulation of the sector simultaneously increased the political power of these corporations and their influence on international organizations and government institutions in the countries where they operated.

\subsection{Mining and CSR at Vale}

Before becoming a large multinational corporation, Vale already had a long history of exploring mineral resources in Brazil. It was created in 1942 as a result of of negotiations between the governments of the United States, England and Brazil during the Second World War, which ensured the Brazilian supply of strategic ores to the war effort. In return, the British government acquired and transferred the iron ore deposits of Itabira Iron Ore Company to the new Brazilian state-owned mining company, Companhia Vale do Rio Doce (CVRD), and the United States government financed operations and export logistics for the company. Based on these operations in Minas Gerais, CVRD consolidated itself as of the 1950s as a major global iron ore exporter (VALE, 2012b).

In the following decades, when the Brazilian military government adopted policies for "occupation" and development of the Amazonian territory, the company expanded its activities to new mineral frontiers in the Brazilian Amazon, where large reserves of bauxite and iron ore were discovered in the 1960s. Japanese companies and the Japanese government, which sought to ensure a safe and cheap supply of natural resources necessary for their industrialization process, also played an important role in this process. However, expectations of improving the living conditions of communities in the region have been dashed and CVRD's activities have produced severe social and environmental impacts (BUNKER, 2000; HALL, 1990).

In the context of the neoliberal reforms of the 1990s, CVRD was sold to a consortium made up of private groups, the Brazilian state-owned pension funds and the holding of Banco Nacional de Desenvolvimento Economico e Social (BNDESPar). In the early 
2000s, the privatization process was deepened through the insertion of the company in the international capital market. The common shares of CVRD, which adopted the name Vale in 2007, started being traded on the Madrid and New York stock exchanges. This meant that, although governments could still play an important role in the direction of the company - for example, via financing, changing environmental laws etc. - the interests of individual and institutional investors became more important (SAES; MURADIAN, 2021).

The adoption of CSR practices at Vale can be understood in this context, in which the company sought to expand its participation in the financial markets. In 2006, the company joined the ICMM and started publishing Sustainability Reports (VALE, 2006). In the post-privatization context, the company also restructured the Vale Foundation, created in 1968, expanding its "social investments" and its "social development" actions. This restructuring reinforced Vale's intention to interfere in social and planning issues, replacing the State's actions, and restricting public spaces for discussion about the conditions for implementing the company's projects (PANTOJA, 2018).

China, unlike Japan, England and the United States, even without agreements with the Brazilian government or financing strategies, ensured the supply of minerals necessary for its industrialization. In the last few decades, Vale has substantially expanded the extraction of natural resources and its activities into new mineral frontiers in Brazil and other countries, sometimes with the support of government policies. In Brazil, the great increase in iron ore extraction occurred due to several acquisitions of mining companies operating in Minas Gerais and new investments in megaprojects, such as the S11D in Carajás (SAES, 2018; SAES; BISHT, 2020). Vale also made several acquisitions and international investments. The most important acquisition was that of Canadian mining company Inco, a major nickel producer with operations in Canada, New Caledonia and Indonesia. In Mozambique, the company won the bid to explore one of the largest coal reserves in the world. Finally, other important investments were made in the extraction of phosphate and potassium used in fertilizers (Brazil, Peru and Argentina), and in the extraction of copper (Peru, Brazil and Chile) (VALE, 2012b).

\section{Methods}

To have a broad overview and understanding of the way Vale operates across these different locations, this research needed robust empirical support and a sound methodology for data collection. However, it could not only base itself on official reports and mainstream media records, as these often leave out claims and argumentations from the people on the ground, from affected families, and from supporting organizations. The EJAtlas offers both a valuable source and research methodology to systematize data around conflicts happening around Vale operations worldwide.

When this research started, in the aftermath of the collapse of the Brumadinho tailings dam, the database already included cases where the Vale company was involved. As the first step, the authors of this paper and other colleagues reviewed this first set of cases and looked for updates. Secondly, the Vale portfolio of projects and operations 
was reviewed and an online keyword search was run using words such as 'conflict', 'protest', 'impact' in different languages (mainly in English, Spanish, and Portuguese). With a selection of cases where conflicts have been recorded, local organizations, academic researchers, and the transnational Vale Affected Peoples' Network have been contacted and invited to participate in the effort of building a public database and a thematic world map of conflicts around Vale operations. The set of cases was reviewed collectively, and data was organized following the EJAtlas database form. The collected information was based on first-hand testimonies, published reports by EJ groups and human rights organizations, scientific articles and official data sources. All data was finally double-checked and moderated by the authors before publication on the online platform.

The EJAtlas thematic map "iEsto no Vale! Isso não Vale! Vale S.A. global operations lead to socio-environmental conflicts" features thirty cases and includes both quantitative and qualitative data, as well as images, references, and a bibliography for each of them (Figure 1). It was publicly released on the International Day of Action for Rivers in March 2019, almost two months after the crime in Brumadinho that left over 270 people dead and an incommensurable contamination of a vast region, including forests and rivers. Also in March, the map was presented at the III Latin American Congress of Political Ecology, held in Bahia, Brazil.

Figure 1. Thematic map of Vale

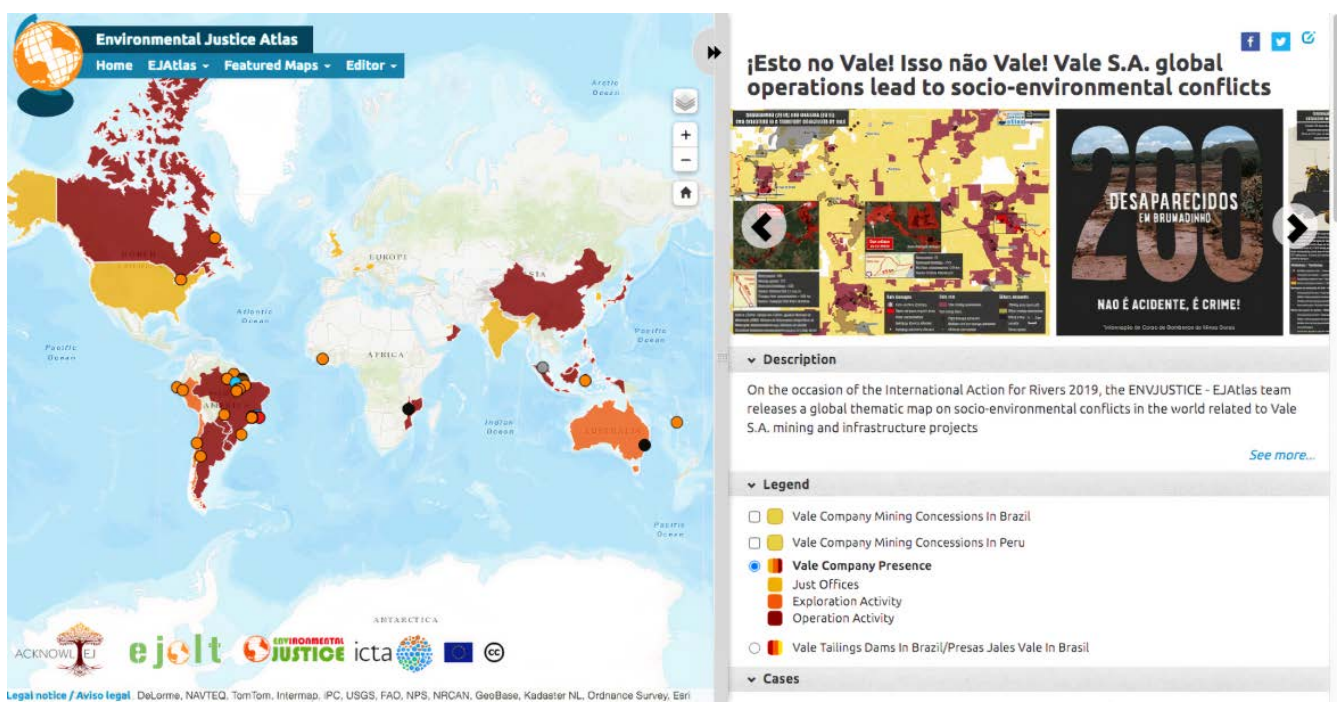

Fonte: https://ejatlas.org/featured/envconflictsvale.

A second phase of the research involved the analysis of environmental conflicts and the comparison of the main characteristics of the conflicts with Vale's CSR discourses and practices. To this end, the company's Sustainability Reports, published between 2006 and 2019, which annually provide information on socio-environmental aspects of 
business activities following the GRI guidelines, were examined. The main objective of this investigation was to identify the CSR discourses and practices applied to the thirty environmental conflicts in the thematic map. However, as the Reports only include information about companies over which Vale has operational control and holds a percentage of participation greater than $50 \%$, it was not possible to investigate CSR in six cases (cases 2, 4, 8, 13, 24 and 26, in Annex I). For the other cases, we made a survey of the CSR practices highlighted as successful by the company itself. These successful practices are called "cases" in the Reports and were reported between 2006 and 2017. In all, 57 CSR practices were found to be related to 19 environmental conflicts in the thematic map. These practices were classified into more frequent themes, which were grouped into two broad categories: communities and the environment. From these categories, discourses and practices were analyzed and contextualised in the light of environmental conflicts.

\section{Results}

\subsection{Main characteristics of the conflicts on the thematic map of Vale}

The catalogued socio-environmental conflicts are located in 10 countries - Brazil, Peru, Australia, Indonesia, Canada, Mozambique, New Caledonia, Argentina, Malaysia and Guinea. In Brazil, there are 18 reported conflicts, located in the states of Pará, Minas Gerais, Espírito Santo, Maranhão, Santa Catarina and Mato Grosso do Sul. In five of the 30 cases (cases 6, 9, 11, 20 and 30), the projects and operations generating conflict have been fully developed by Vale since their implementation. In most other cases (in 23 of them), Vale worked with other companies, through shareholdings in projects or companies, or partially or fully acquired operations in progress - and, currently, it has already disposed of nine of these participations or projects. There is only one case in which Vale does not have a direct participation in the operations (case 21). However, the company still plays an important role as the only supplier of the ore benefited by the pig iron plants that generate the conflict. In another case (case 8), Vale never planned or developed any operation, but had research application processes with the Brazilian National Mining Agency in the region when the conflict started.

Although all catalogued cases are related to mining, there are important variations with respect to the stage of the production chain that is primarily responsible for generating each conflict (Annex I, column "Activities that generate the conflict"). In other words, conflicts are not always restricted to the extraction and processing of ores. There are, for example, three cases in which the activity that generates the conflict is the production of energy inputs for mining through hydroelectric plants (cases 1 and 4) and palm plantations (case 5). On the other hand, in the final stages of the chain, two other conflictive projects concern the export of Brazilian iron ore to international markets: the Vale's maritime terminals in the city of Vitória (Espírito Santo) (case 6) and the company's Teluk Rubiah Ferry Terminal in Malaysia (case 25).

The groups mobilized in environmental conflicts involving Vale are, in large part, vulnerable segments of society (Annex I, column "Actors mobilizing"). These groups have 
their lives and livelihoods threatened disproportionately by environmental degradation and expropriations resulting from the exploitation of natural resources (SCHEIDEL et al., 2020). In more than half of the catalogued conflicts (in 17 of them), indigenous populations and traditional communities are important players in the resistance to Vale's projects and operations. Other vulnerable groups, especially farmers and fishermen, whose activities are directly affected by environmental impacts from mineral operations, are present in most conflicts. In Brazil, in five cases in the states of Pará and Maranhão (cases 4, 9, 17, 21 and 30), there are also landless peasants present, which reflects the existence of land conflicts that are often aggravated by mining expansion.

The outcomes of catalogued environmental conflicts (Annex I, column "Outcomes of conflicts") are often unfavourable to resistance movements, and in many cases there are important threats to the livelihoods of vulnerable groups. In one third of the conflicts, there were expropriations or migrations of populations. These cases are mainly located on commodity extraction frontiers, where there is a greater presence of indigenous populations and traditional communities. In Brazil, for example, expropriations occurred mainly in the Amazon, with five cases in the state of Pará (cases 2, 4, 5, 17 and 30). In addition, violent forms of repression have also been reported in several cases, with the criminalization of activists taking place in different countries (Brazil, Canada, Peru, Indonesia, Mozambique and New Caledonia).

On the other hand, favourable results for the mobilized social groups are mainly restricted to compensation payments for socio-environmental damages and to successful court decisions. There was compensation in 12 of the cases analysed. In many of these cases, however, this was not the main demand of the mobilized groups; on the contrary, the demand for fair compensation occurs after unsuccessful attempts to stop conflicting projects (for example, cases 1, 3, 4 and 30). In the case of dam failures in Mariana and Brumadinho, where there is irreversible socio-environmental damage, fair financial compensation is the main demand of the mobilized groups. Successful court decisions, in turn, appear as a result of conflicts in more than a third of cases and may indicate that many of these projects are not developed in accordance with the laws of the respective countries.

\subsection{Vale's CSR discourses and practices related to communities}

CSR practices related to communities are very diverse, ranging from the training of labour for Vale's direct activities to broader issues related to the development of the regions where the company's projects are located (Figure 2). A greater number of practices were found in projects in Mozambique, New Caledonia and Pará, mainly in operations started between 2008 and 2016 (cases 9, 17, 20, 22 and 30).

This may indicate that these practices are particularly important in the period of installation of the projects, as a way of anticipating conflicts and containing possible resistance from different groups. However, despite the variety of actions and themes, the analysis of the set of practices also indicates that they are based, in general terms, on a particular vision of "local development" or "territorial development", which does not necessarily respond to grievances and claims faced by communities. Moreover, this interest 
in local development is not always reflected in a long-term commitment on the part of Vale: in almost a third of registered cases, the company ended up selling its stake in the project or subsidiary without assuming responsibility for its socio-environmental liabilities.

Figure 2. Vale's CSR practices related to communities

\begin{tabular}{|c|c|c|c|c|}
\hline $\begin{array}{l}\text { Cases } \\
(\text { An- } \\
\text { nex 1) }\end{array}$ & $\begin{array}{l}\text { Training of } \\
\text { labor }\end{array}$ & $\begin{array}{l}\text { Suppliers / human } \\
\text { resources / other local } \\
\text { activities }\end{array}$ & $\begin{array}{l}\text { Education / culture / } \\
\text { health }\end{array}$ & Others \\
\hline 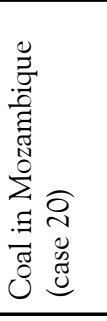 & $\begin{array}{l}\text { Diversified } \\
\text { workforce } \\
(2008) \\
\text { Program trains } \\
\text { workers in } \\
\text { Mozambique } \\
(2013)\end{array}$ & $\begin{array}{l}\text { Actions in Mozambique } \\
(2014)\end{array}$ & $\begin{array}{l}\text { Fighting malaria in } \\
\text { Africa (2013) }\end{array}$ & $\begin{array}{l}\text { Resettlement in } \\
\text { Mozambique (2009) } \\
\text { Vale Foundation } \\
\text { arrives in Mozam- } \\
\text { bique (2010) } \\
\text { The spirit of the } \\
\text { relationship (2008) }\end{array}$ \\
\hline 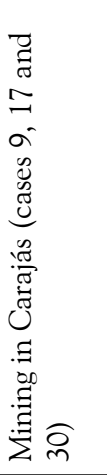 & $\begin{array}{l}\text { Education that } \\
\text { transforms } \\
\text { (2011) }\end{array}$ & $\begin{array}{l}\text { Fishing at Boqueirão } \\
\text { beach (2009) } \\
\text { Strengthening family } \\
\text { farming (2017) } \\
\text { More security in the } \\
\text { implementation of the } \\
\text { S11D Project (2013) } \\
\text { Support for family far- } \\
\text { ming (2014) } \\
\text { Program Act (2017) }\end{array}$ & $\begin{array}{l}\text { Preserving history } \\
\text { (2011) } \\
\text { No to child sexual } \\
\text { exploitation (2013) } \\
\text { Atitude Ambiental } \\
\text { receives Eco } 2010 \text { award } \\
\text { (2010) }\end{array}$ & $\begin{array}{l}\text { Necessary transfor- } \\
\text { mation (2007) }\end{array}$ \\
\hline 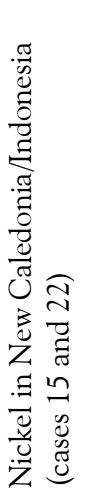 & $\begin{array}{l}\text { Hands-on } \\
(2009)\end{array}$ & & $\begin{array}{l}\text { Vale supports rescue of } \\
\text { native languages in Bra- } \\
\text { zil and New Caledonia } \\
\text { (2010) } \\
\text { Eye screening program } \\
\text { and cataract surgery } \\
\text { in Dompu, Indonesia } \\
\text { (2017) } \\
\text { Preserve the language. } \\
\text { Strengthen culture } \\
\text { (2008) } \\
\text { Easy reading (2008) }\end{array}$ & $\begin{array}{l}\text { Sustainable Pact } \\
(2008) \\
\text { Support actions for } \\
\text { communities (2009) }\end{array}$ \\
\hline
\end{tabular}




\begin{tabular}{|c|c|c|c|c|}
\hline 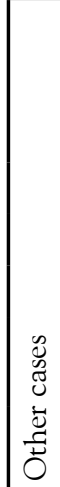 & $\begin{array}{l}\text { Investments } \\
\text { that make } \\
\text { a difference } \\
(2008)\end{array}$ & $\begin{array}{l}\text { Novo Rumo Project } \\
(2016) \\
\text { Program Act (2014) } \\
\text { Healthy Lives (2008) } \\
\text { Franco Dialogue (2008) } \\
\text { Agreement benefits Chi- } \\
\text { lean pirquineros (2010) } \\
\text { Reengaging employees in } \\
\text { Canada (2011) }\end{array}$ & Empower to grow (2009) & $\begin{array}{l}\text { Development of } \\
\text { Grande Vitória } \\
\text { (2009) } \\
\text { The struggle for } \\
\text { decent work (2007) } \\
\text { Challenge won by } \\
\text { working together } \\
\text { (2013) }\end{array}$ \\
\hline
\end{tabular}

Fonte: own elaboration based on Vale's Sustainability Reports (2006-2019).

In the Moatize coal project in Mozambique, CSR practices reinforce massive displacement of hundreds of families as the only alternative to communities. The resettlement plans were presented together with various "social investments" in health, education, culture, sports, urbanization and productive activities, coordinated by the Vale Foundation (VALE, 2009, p.86). Also, pointing out the need to qualify labour for its enterprise and for the development of the region, Vale has financed various training and education programmes since the implementation of this project. This set of actions seeking to promote the "social and economic development of communities" (VALE, 2010, p.79) are introduced as Vale's charitable actions, anticipating democratic decision-making processes about the future of the communities. Possible disagreements with Vale policies, including those based on the demands of families whose conditions of subsistence and self-sufficiency may be compromised, are targeted by CSR practices to soften dissent even when not responding to peoples' demands. The "Spirit of the relationship", for example, includes "participatory dialogue" as "fundamental to the negotiation of resettlement of residents" (Vale, 2008, p.67), but says nothing about important local mobilizations against the project and about the violence against activists on these occasions.

In the French territory of New Caledonia, where it is estimated that about 25\% of the global nickel reserve is located, CRS practices were central to creating a "Pact for Sustainable Development" (Vale, 2008, p. 84) between Vale and communities, which was intended to eliminate more radical mobilizations against the Goro nickel project (HOROWITZ, 2015). Despite additional studies of environmental impacts and the introduction of voluntary environmental programs, such as the reforestation of degraded areas, important impacts of the project were maintained such as the discharge of industrial effluents into the ocean and the potential contamination of the sea and channels by mercury and sulfuric acid, criticized since 2002 by the local Kanak ethnic group funded advocacy environmental group Rhéébù Núu ("country eye"). Since the end of 2019, Vale finally announced that it intends to sell its stakes in New Caledonia and start negotiations with Australian companies, an announce- 
ment that increased the conflict with nationalist and indigenous movements that are in favour of New Caledonian independence and oppose to this corporate strategy. Vale currently threatens to end nickel operations, compromising thousands of jobs in the archipelago (ROGER, 2020).

In Mendoza (Argentina), the Rio Colorado potash project was purchased by Vale in 2009 and would have been one of the largest potash projects in the world (from 2,4 to 4.3 million tons per year), intended to supply the Brazilian demand for fertilizers (WAGNER; GIRAUD, 2011). In a country like Argentina, where mining companies enjoy important tax privileges granted by national law, Vale tried to obtain more privileges and ignored commitments to the provincial states involved in the project, exerting pressure by hiring direct jobs (GIRAUD, 2013). Despite initial projections of increased production, in 2013, Vale stopped the project because of an "international uncertainty" regarding the price of potash. About 5,000 workers were left without jobs, while Mendoza is now looking for a new investor to develop the mega-project.

In Peru, exploration licenses for La Morada project were obtained in without the agreement of the owners involved, and the environmental license was approved without complying with all the required studies (case 16). In the Bayóvar project, Vale acted through a foundation, Fundação Comunal Sechura, in order to promote "social works" in the region to bring about "prosperity" and "sustainable development" (NEYRA, 2020). However, while the company said it heard the "demands" of the communities and was committed to "taking advantage of the project's potential and leveraging activities in various chain stages" (VALE, 2008, p.69), its activities affected the livelihood of thousands of people and local economic activity (case 3). The phosphate deposit of the Bayóvar project was located under the peasant community of San Martín de Sechura with 60 thousand inhabitants and 700 thousand hectares. Phosphate leaks in the Bay of Parachique affected the cultivation of scallops, as denounced by the Artisanal Fisheries Front of the Bay of Parachique and Bayóvar. The health of workers in Caleta de Puerto Rico (Piura) was also affected by the dispersion of polluting particles in the air, as demonstrated by the Center for Occupational Health and Environmental Protection. In some cases, the reactions to the mobilizations against the project were very violent. During the crackdown on the May 2012 strike, called by the Defense Front, the police killed two fishermen. Violent reactions to protests and criminalization of activists were also reported in the La Morada project, where Vale subsidiary Miski Mayo formed security groups that operated as paramilitary groups, threatening and assaulting community leaders and their families. In some cases, these leaders were denounced by the company and convicted by the courts (NEYRA, 2020).

\subsection{Vale's CSR discourses and practices related to the environment}

The practices and discourses related to the environment and applied to the analysed cases are divided into two main groups: i) technological efficiency in the 
use of resources or waste production; and ii) environmental conservation (Figure 3). Regarding technological efficiency, Vale's Reports highlight the use of new technologies to reduce water and fuel consumption and greenhouse gas emissions. This increase in the efficiency of the production processes can be a measure to reduce production costs or an adaptation to environmental legislation. In one case (case 6), the introduction of a new technology (Wind Fence), aimed at reducing the emission of iron ore particles in the Tubarão Complex (Vitória, Espírito Santo), also responded to protests from organizations pointing out the harmful effects of pollution on the health of the local population. In most of the environmental conflicts analysed, however, technological solutions do not seem to be sufficient from the perspective of the mobilized groups. On the contrary, there is an important set of new investments that can reproduce or produce new environmental injustices.

Figure 3. Vale's CSR practices related to the environment

\begin{tabular}{|c|c|c|c|}
\hline \multirow{2}{*}{$\begin{array}{l}\text { Cases } \\
\text { (Annex 1) }\end{array}$} & \multicolumn{2}{|l|}{ Technological innovations } & \multirow{2}{*}{$\begin{array}{l}\text { Environmental Conserva- } \\
\text { tion } \\
\text { Biodiversity }\end{array}$} \\
\hline & $\begin{array}{l}\text { Climate change and } \\
\text { energy }\end{array}$ & Water / other & \\
\hline 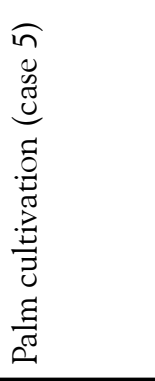 & $\begin{array}{l}\text { Biodiesel on Vale's tracks } \\
\text { (2006) } \\
\text { Sustainable Entrepreneur- } \\
\text { ship (2008) } \\
\text { Research Incentive } \\
\text { (2009) } \\
\text { Betting on renewable } \\
\text { fuels (2011) }\end{array}$ & & \\
\hline 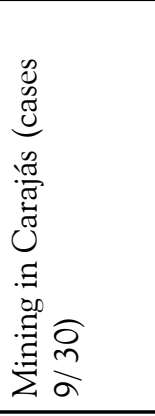 & $\begin{array}{l}\text { Innovation gains (2014) } \\
\text { S11D and Carnalita: in- } \\
\text { novation and technology } \\
\text { (2011) (case 30) } \\
\text { The path of sustainable } \\
\text { mining (2012) (case 30) }\end{array}$ & $\begin{array}{l}\text { Sossego Mine recircu- } \\
\text { lates more than } 99 \% \text { of } \\
\text { the water it uses (2012) } \\
\text { (case 9) } \\
\text { Rationalization of water } \\
\text { use in the Sossego mine } \\
\text { (2006) (case 9) } \\
\text { The path of sustainable } \\
\text { mining (2012) (case 30) }\end{array}$ & $\begin{array}{l}\text { Biodiversity conservation } \\
\text { is awarded by the UN } \\
(2010)\end{array}$ \\
\hline 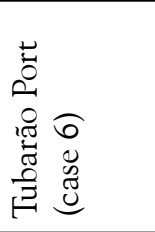 & $\begin{array}{l}\text { Vale installs state-of-the- } \\
\text {-art weather radar (2013) } \\
\text { Economy at Vale's ports } \\
\text { (2016) }\end{array}$ & $\begin{array}{l}\text { Innovative technology } \\
\text { in atmospheric control } \\
(2009)\end{array}$ & Tubarão Port (ES) (2016) \\
\hline
\end{tabular}




\begin{tabular}{|c|c|c|}
\hline 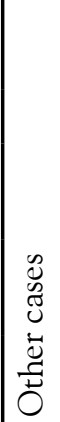 & $\begin{array}{l}\text { System reduces emissions } \\
\text { in coal mines (2012) }\end{array}$ & $\begin{array}{l}\text { Restoration of degraded } \\
\text { areas in Indonesia (2011) } \\
\text { Global strategies (2008) } \\
\text { Ecological Blankets } \\
(2011) \\
\text { Protection of reserves in } \\
\text { New Caledonia (2012) } \\
\text { Environmental attitude } \\
\text { (2007) }\end{array}$ \\
\hline
\end{tabular}

Source: own elaboration based on Vale's Sustainability Reports (2006-2019).

In 2008, when it drew up its Corporate Guidelines on Climate Change and Carbon, Vale was the only Latin American company on the Carbon Leadership Index, which reports companies listed on the New York Stock Exchange considered to be models in transparency and climate change management (VALE, 2008). In this context, Vale has developed numerous projects and research related to the generation of energy from different sources - hydroelectric, wind, biomass, solar and biofuel, including important investments in the highly controversial Belo Monte Hydroelectric Plant (VALE, 2011; DEL BENE et al., 2018). The Vale's thematic map includes at least three cases of conflictive projects (cases 1, 4 and 5) which are considered strategic for reducing carbon emissions and for ensuring the energy supply of the company's operations.

The conflict that perhaps draws most attention for having great prominence in climate change practices is caused by palm production in the Brazilian Amazon. The practice "Biodiesel on Vale's tracks" describes the first research carried out by the company to evaluate the use of palm biodiesel as fuel for its locomotives. In addition to the transition to a renewable energy source, Vale also indicated a possible contribution to the "social development" of regions in the North and Northeast of Brazil by encouraging biodiesel production (VALE, 2006, p. 73). In 2011, this project was expanded from the acquisition of the shareholding control of Biopalma Amazônia AS in Pará. Vale intended to expand the planted area of 35 thousand hectares in 2011 to 80 thousand hectares in 2013. This expansion would occur, according to the practice "Betting on renewable fuels" (VALE, 2011, p.74), in areas of abandoned pastures.

The environmental conflict resulting from this expansion of palm cultivation, however, indicates important impacts on territories where indigenous and quilombola communities live. The Tembé indigenous people were affected by the use of pesticides and the diversion of water courses for irrigation of crops, which caused a reduction in the water flows of the streams, the death of fish and the increase of diseases among the community. In 2013, researchers examined the waters of the region and identified residues of the highly toxic substance endosulfan, which was banned in Brazil in 2010. The indigenous people began to demand compensation and mitigation of the impact as of 2012, including carrying out occupations of the Biopalma plantations. In these protests, members of quilombola communities also participated, accusing 
Biopalma and Vale of land grabbing. Vale had acquired farms in order to expand palm oil production that covered quilombola territories, with open recognition requests, aggravating the land conflict in the region. In 2018, a young quilombola leader resisting the occupation of illegal land for the cultivation of palm was brutally murdered.

Vale's Sustainability Reports highlight also the company's role in conserving biodiversity. In Brazil, the company's operations in the Carajás National Forest are presented as models of environmental preservation, as they occupy a small part (3\%) of the reserve's 412 thousand hectares of land. In this area, managed by Vale and the Brazilian government, there are important mineral reserves that are protected from human occupation and can therefore be used for future mineral exploration. The most important recent example of expanding operations within the National Forest is the S11D, which is the largest project in both the history of Vale and iron ore mining in the world. The countless cases in the Sustainability Reports present this iron ore project as an example of sustainable mining. The process to make it viable, however, was highly contested and resulted in environmental injustice generated due to environmental conservation.

During the S11D environmental licensing, environmental legislation was relaxed and Vale convinced environmental authorities to increase impacts on the canga ecosystem, which has high ecological importance. In return, the project would only be authorized if Vale guaranteed the preservation of an environmental area similar to the one impacted. To comply with the condition, Vale acquired several properties outside the limits of the National Forest. About 5,000 hectares of the areas purchased for compensation were federal public lands occupied by squatters or claimed by landless families for the creation of settlements. Another thousand hectares of settlements were acquired by Vale without the consent of the National Institute for Colonization and Agrarian Reform (INCRA). The acquisitions were followed by violent expropriations and protests by landless families and rural workers. Despite the claims and expropriations of dozens of families, the Campos Ferruginosos National Park was created in 2017.

\section{Conclusion}

This paper examined the apparent contradiction of high CSR standards in large multinationals in the mining sector coexisting with many socio-environmental conflicts, and how CSR measures can be turned into means for further profit generation. In the past two decades, Vale has expanded its operations in mineral extraction frontiers around the world, generating important socio-environmental impacts, while also adopting several CSR standards and practices. The main contribution of this analysis is to show that, even when Vale considers its performance both responsible and exemplary, the company reproduces environmental injustices and is therefore rather practicing CSIR. The cases studied suggest, in the first place, that part of the social demands and mobilizations do not seem to be considered nor do they receive the attention of CSR practices. As indicated in several studies (SHAMIR, 2004; 
BANERJEE, 2008; HOROWITZ, 2015; GODFRID, 2016), claims capable of calling into question the economic interests and legitimacy of large corporations tend to be strategically marginalized in the process of adopting CSR initiatives. Second, the adoption of such initiatives, in several cases analysed, contributes to reinforcing or producing new environmental injustices.

The social groups marginalized by CSR practices in the cases analysed are, in general, vulnerable populations and indigenous peoples, whose lives and livelihoods are threatened by environmental degradation and expansion of mineral extraction. The exclusion of the grievances and claims of these communities seems to be reinforced by Vale's use of CSR. Vale's practices aimed at education, culture, labour training and other "social investments" are articulated around a particular notion of "local development" or "territorial development", which assumes the uprooting and detachement of communities from their territories and livelihood. This particular notion of territorial development, which results from undemocratic decision-making processes and excludes plural perspectives and values, is fully compatible with the company's interests, as it does not compromise its territorial expansion and the growing private appropriation of natural resources. Thus, when channeling multiple demands, strategically selecting those compatible with its projects, Vale's CSR practices do not necessarily seek to solve social and environmental problems, but rather "solve", smooth, depoliticize or neutralize environmental conflicts, or even make them purely technical problems (LI, 2015; ACSELRAD, 2018; BROCK, DUNLAP, 2018; NEYRA, 2020).

This attempt to neutralize conflicts appears to be successful in the company's Sustainability Reports, where important aspects of environmental conflicts described in Vale's thematic map are not portrayed, much less the violence exercised against actors and groups mobilized. The main readers of these Reports, however, are not those actors and other stakeholders who are impacted by the projects, but investors (shareholders and their representatives), for whom it essentially matters that the "social risks" of investments are prevented or eliminated (ACSELRAD, 2018; MAHER, 2019). In other words, CSR can legitimize the company's performance from the perspective of some groups, while for other groups, even exemplary actions described in the Reports, translate into CSIR practices. In fact, when analysing practices aimed at environmental sustainability at Vale, this paper shows that the costs of investments in environmental conservation or reductions in carbon emissions often fall on local communities and produce new environmental injustices. These contradictions, however, do not resonate in the evaluations and indicators of institutions that inform investors, in which Vale often appears very well placed.

Initiatives such as that of the thematic map of Vale are important, therefore, for reporting environmental conflicts and resistances that visibilize CSIR practices contrasting with the discourses and assessments of corporate performance indicators and reports. Despite being absent from corporate documents, resistance to Vale's projects and the expansion of mineral extraction frontiers is occurring in all catalogued 
environmental conflicts. In many cases, actors and groups resist because their sources of livelihood are threatened by environmental degradation, and thus by resisting they also act for EJ and global sustainability (MARTÍNEZ-ALIER, 2002, SCHEIDEL et al., 2020). In this sense, the visibility of these actors and their claims is an important step for corporations to be held accountable for their socio-environmental liabilities, and also for them not to continue to systematically transfer socio-environmental costs to third parties.

\section{Acknowledgments}

We would like to thank researchers, activists and movements that contributed to build the database, in particular the authors of the cases and the following organizations: Movimento d@s Atingid@spor Barragens (MAB), Articulação Internacional da Atingid@s pela Vale, Movimento Aguas de Gandarela, FASE, Jubileu Sul Brasil, Movimento pela Soberania Popular na Mineração (MAM), the research group of Mapa de Conflitos envolvendo Injustiça Ambiental e Saúde no Brasil, Mining Watch Canada e JATAM Indonesia. We also thank Grettel Navas and Sara Mingorría for their valuable suggestions in the analysis of the cases and Annalisa Powell and Naima Kraushaar-Friesen for the English revision and valuable comments to enhance the text clarity. Co-authors from ICTA-UAB acknowledge support from ERC Advanced Grant "EnvJustice" GA 695446.

\section{References}

ACSELRAD, H.(ed.). Políticas territoriais, empresas e comunidades: o neoextrativismo e a gestão empresarial do" social". Rio de Janeiro: Garamond, 2018.

ACSELRAD, H.; MELLO, C.; BEZERRA, G. O que é Justiça Ambiental. Rio de Janeiro: Garamond, 2009.

ANTONELLI, M. Minería transnacional y el dispositivos de intervención en la cultura, en Minería transnacional y narrativas del desarrollo y resistencias sociales. In: SVAMPA, M.; ANTONELLI, M.(ed.). Minería transnacional, narrativas del desarrollo y resistencias sociales. Buenos Aires: Biblos, p.51-100, 2009.

BANERJEE, S.B. Corporate social responsibility: The good, the bad and the ugly. Critical sociology, v.34, p.51-79, 2008.

BÖHLING, K; MURGUÍA, D; GODFRID, J. Sustainability reporting in the mining sector: Exploring its symbolic nature. Business\&society, v.58, p.191-225, 2017. 
BROCK, A.; DUNLAP, A. Normalising corporate conter insurgency: Engineering consent, managing resistance and greening destruction around the Hambach coal mine and beyond. Political Geography, v.62, p. 33-47, 2018.

BULLARD, R.D. Unequal Protection: Environmental Justice and Communities of Color. San Francisco: Sierra Club Books, 1994.

BUNKER, S. Joint ventures em ambientes frágeis: o caso do alumínio na Amazônia. Novos Cadernos NAEA, v.3, p.5-45, 2000.

CARROLL, A.B. Corporate Social Responsibility Evolution of a Definitional Construct. Business\&Society, v.38, n.3, p.268-295, 1999.

CHO, C.H.; PATTEN, D.M. Green accounting: Reflections from a CSR and environmental disclosure perspective. Critical Perspectives on accounting, v.24, n.6, p.443-447, 2013.

DEL BENE, D.; SCHEIDEL, A.; TEMPER, L. More dams, more violence? A global analysis on resistances and repression around conflictive dams through co-produced knowledge. Sustainability science, v.13, n.3, p.617-633, 2018.

GARRIGA, E.; MELÉ, D. Corporate Social Responsibility Theories: Mapping the Territory. Journal of Business Ethics, v;53, p.51-71, 2004.

GODFRID, J. La estrategia comunicacional en el sector mega-minero. Question, v.1, n.50, 2016.

HALL, A. Developing Amazonia: Deforestation and Social Conflict in Brazil's Carajás Programme. Manchester: Manchester University Press, 1990.

HIMLEY, M. Global mining and the uneasy neoliberalization of sustainable development. Sustainability, v.2, n.10, p.3270-3290, 2010.

HOROWITZ, L.S. Culturally articulated neoliberalisation: corporate social responsibility and the capture of indigenous legitimacy in New Caledonia. Transactions of the Institute of British Geographers, v.40, p.88-101, 2015.

HUMPHREYS, D. The Remaking of the mining industry. New York, Hampshire: Palgrave Macmillan, 2015.

JENKINS, H. Corporate social responsibility and the mining industry: conflicts and constructs. Corporate Social Responsibility and Environmental Management, v.11, p23-34, 2004.

LI, F. Unearthing Conflict: Corporate Mining, Activism, and Expertise in Peru. Durham, NC: Duke University Press, 2015.

MAHER, R. De-contextualized Corporate Human Rights Benchmarks: Whose Perspective Counts? Business and Human Rights Journal, v.5, 2020.

MARTÍNEZ-ALIER, J. The environmentalism of the poor: a study of ecological conflicts and 
valuation. Cheltenham: Edward Elgar, 2002.

NEYRA, R. Conflictos socioambientales en el Perú, Violencia y extractivismo. Quito: Editorial Abya Yala, 2020.

PANTOJA, I. Ação empresarial e planejamento social privado: um estudo de caso sobre relações empresa-sociedade. In: ACSELRAD, H. (ed.). Políticas Territoriais, Empresas e Comunidades. O neoextrativismo e a gestão empresarial do "social". Rio de Janeiro, Garamond, p.235-260, 2018.

PARSONS, R, LACEY J, MOFFAT K. Maintaining legitimacy of a contested practice: How the minerals industry understands its "social licence to operate." Resources Policy, v.41, p.83-90, 2014.

PORTO, M.F.; FINAMORE, R. Riscos, saúde e justiça ambiental: o protagonismo das populações atingidas na produção de conhecimento. Cien. Saude Colet, v.17, p.1493-1501, 2012

PRNO, J.; SLOCOMBE, D.S. Exploring the origins of "social license to operate" in the mining sector: Perspectives from governance and sustainability theories. Resources Policy, v.37, n.3, p.346-357, 2012.

RIERA, M.; IBORRA, M. Corporate social irresponsibility: review and conceptual boundaries. European Journal of Management and Business Economics, v.26, n.2, p.146-162, 2017.

ROCHE, C.; THYGESEN, K.; BAKER, E.(eds.). Mine Tailings Storage: Safety Is No Accident. A UNEP Rapid Response Assessment. United Nations Environment Programme and GRID-Arendal, Nairobi and Arendal, 2017.

ROGER, P. Le sort d'une usine de nickel menacée de fermeture en Nouvelle-Calédonie s'immisce dans la campagne du référendum. Le Monde. 9 sept 2020. https://www.lemonde.fr/economie/article/2020/09/09/nouvelle-caledonie-1-australien-ncr-renonce-au-rachat-de-l-usine-de-nickel-detenue-par-le-bresilien-vale_6051509_3234.html

SAES, B.M. Comércio ecologicamente desigual no século XXI: evidências a partir da inserção brasileira no mercado internacional de minério de ferro. Rio de Janeiro: Garamond, 2018.

SAES, B.M.; BISHT, A. Iron ore peripheries in the extractive boom: A comparison between mining conflicts in India and Brazil. The Extractive Industries and Society, v.7, n.4, p.1567-1578, 2020.

SAES, B.M.; MURADIAN, R. What misguides environmental risk perceptions in corporations? Explaining the failure of Vale to prevent the two largest mining disasters in Brazil. Resources Policy, v.72, p.102022, 2021.

SCHEIDEL, A.; DEL BENE, D.; LIU, J.; NAVAS, G.; MINGORRÍA, S.; DEMARIA, F.; ÁVILA, S.; ROY, B.; ERTOR, I.; TEMPER, L.; MARTÍNEZ-ALIER, J. Environmental conflicts and defenders: A global overview. Global Environmental Change, v.63, p.102104, 2020. 
SHAMIR, R. The de-radicalization of corporate social responsibility. Critical Sociology, v.30, n.3, p.669-689, 2004.

TEMPER, L.; DEL BENE, D.; MARTINEZ-ALIER, J. Mapping the Frontiers and Front Lines of Global Environmental Justice: The EJAtlas. Journal of Political Ecology, v.22, n.1, p.255-278, 2015.

TEMPER, L.; DEMARIA, F.; SCHEIDEL, A., DEL BENE, D.; MARTINEZ-ALIER, J. The Global Environmental Justice Atlas (EJAtlas): ecological distribution conflicts as forces for sustainability. Sustainability Science, v. 13, n. 3, p. 573-584, 2018.

VALE. Relatório de Sustentabilidade. Rio de Janeiro: Vale, 2006-2018. http://www.vale.com/ brasil/PT/investors/information-market/annual-reports/sustainability-reports/Paginas/default. aspx

VALE. Vale - Nossa História. Rio de Janeiro: Brasil Verso Editora, 2012 b.

WAGNER, L., GIRAUD, M. El proyecto minero Potasio Río Colorado: Conflicto socioambiental, impactos regionales y falta de integralidad en la evaluación ambiental. In: ALIMONDA, H. (ed.). La Naturaleza colonizada: Ecología política y minería en América Latina. Bs As: CLACSO, p. 261-288, 2011.

WAGNER, L. Environmental Justice. In: KALTMEIER, O.; TITTOR, A.; HAWKINS, D.; ROHLAND, E.(eds.) The Routledge Handbook to the Political Economy and Governance of the Americas. Routledge, p.93-102, 2020.

GIRAUD, M. Privilegios inadmisibles. In: LEWKOWICZ, J. Por qué suspendió el proyecto, Página 12, 1st April 2013. https://www.pagina12.com.ar/diario/economia/2-217039-2013-04-01. html 


\section{Annex}

\section{Annex 1. Environmental conflicts on the thematic map of Vale}

\begin{tabular}{|c|c|c|c|c|c|c|c|c|c|c|c|c|c|c|c|c|c|c|c|c|c|}
\hline \multirow[b]{3}{*}{ Case } & \multirow[b]{3}{*}{$\begin{array}{l}\text { Project or } \\
\text { opera- } \\
\text { tions and } \\
\text { location } \\
\text { (State if } \\
\text { located in } \\
\text { Brazil, and } \\
\text { Country) }\end{array}$} & \multicolumn{10}{|c|}{ Actors mobilizing in conflicts } & \multicolumn{10}{|c|}{ Conflict outcomes } \\
\hline & & \multicolumn{7}{|c|}{ Vulnerable groups } & \multirow[b]{2}{*}{ 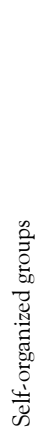 } & \multirow[b]{2}{*}{ 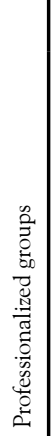 } & \multirow[b]{2}{*}{ 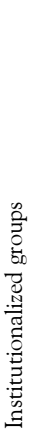 } & \multicolumn{5}{|c|}{ Positive } & \multicolumn{5}{|c|}{ Negative } \\
\hline & & 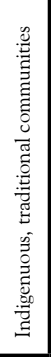 & 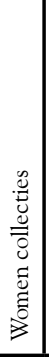 & 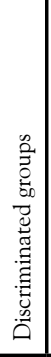 & 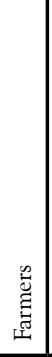 & 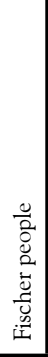 & 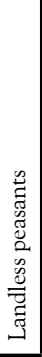 & 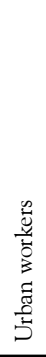 & & & & 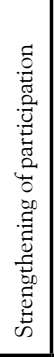 & 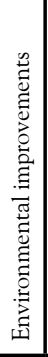 & 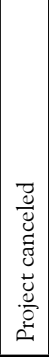 & 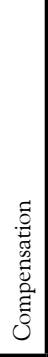 & 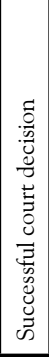 & 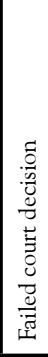 & 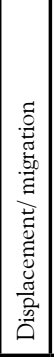 & 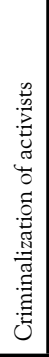 & 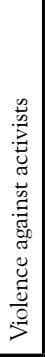 & 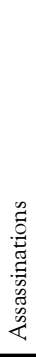 \\
\hline$\underline{1}$ & $\begin{array}{l}\text { Hydroelectric } \\
\text { Plant Aimo- } \\
\text { rés (Minas } \\
\text { Gerais, } \\
\text { Brazil) }\end{array}$ & & & & & & & & & & & & & & & & & & & & \\
\hline$\underline{2}$ & $\begin{array}{l}\text { Bauxite } \\
\text { mining (Pará, } \\
\text { Brazil) }\end{array}$ & & & & & & & & & & & & & & & & & & & & \\
\hline$\underline{3}$ & $\begin{array}{l}\text { Bayóvar } \\
\text { phosphate } \\
\text { project } \\
\text { (Peru) }\end{array}$ & & & & & & & & & & & & & & & & & & & & \\
\hline 4 & $\begin{array}{l}\text { Belo Monte } \\
\text { Hydroelectric } \\
\text { Plant (Pará, } \\
\text { Brazil) }\end{array}$ & & & & & & & & & & & & & & & & & & & & \\
\hline 5 & $\begin{array}{l}\text { Palm plan- } \\
\text { tation (Pará, } \\
\text { Brazil) }\end{array}$ & & & & & & & & & & & & & & & & & & & & \\
\hline$\underline{6}$ & $\begin{array}{l}\text { Tubarão } \\
\text { Maritime } \\
\text { Terminal (Es- } \\
\text { pírito Santo, } \\
\text { Brazil) }\end{array}$ & & & & & & & & & & & & & & & & & & & & \\
\hline 7 & $\begin{array}{l}\text { Capão Xavier } \\
\text { iron ore mine } \\
\text { (Minas Ge- } \\
\text { rais, Brazil) }\end{array}$ & & & & & & & & & & & & & & & & & & & & \\
\hline$\underline{8}$ & $\begin{array}{l}\text { Mining in the } \\
\text { RENCA Re- } \\
\text { serve (Pará, } \\
\text { Brazil) }\end{array}$ & & & & & & & & & & & & & & & & & & & & \\
\hline$\underline{9}$ & $\begin{array}{l}\text { Salobo and } \\
\text { Sossego co- } \\
\text { pper projects } \\
\text { (Pará, Brazil) }\end{array}$ & & & & & & & & & & & & & & & & & & & & \\
\hline
\end{tabular}




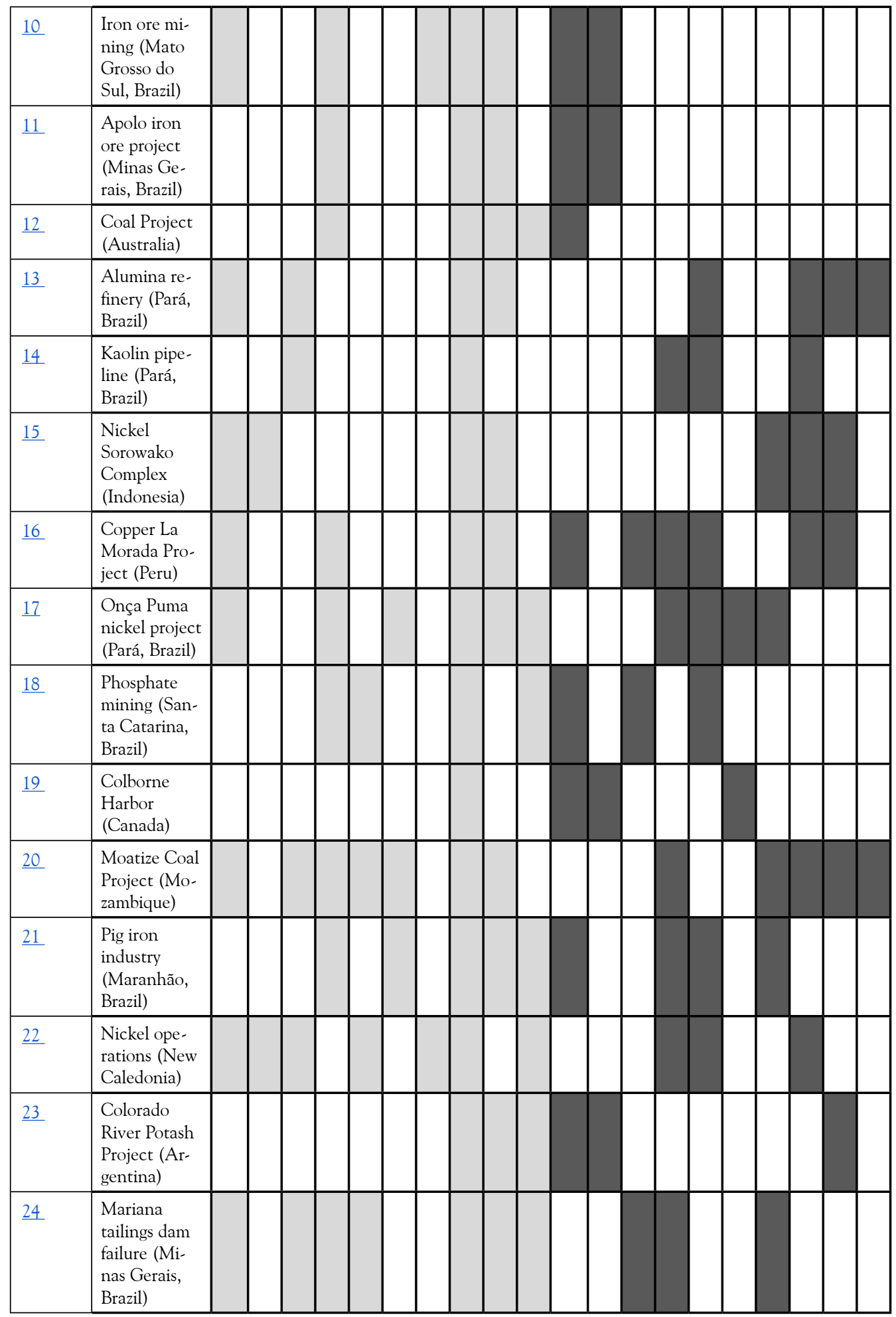




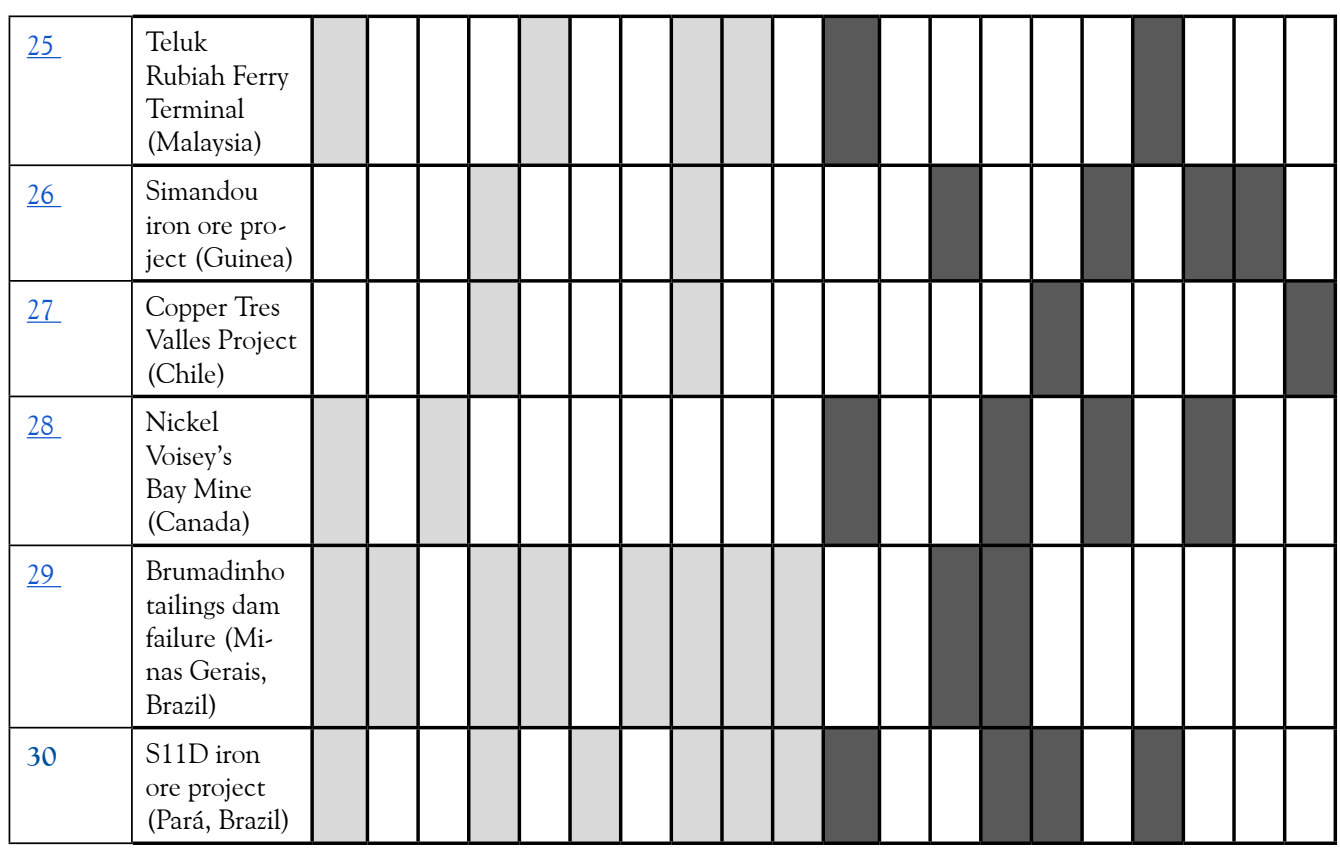




\section{Beatriz Macchione Saes}

$\square$ beatriz.saes@unifesp.br

ORCiD: https://orcid.org/0000-0001-5256-1457
Submitted on: 26/03/2021

Accepted on: 22/05/2021

2021;24e:0014

\section{Daniela Del Bene}

$\square$ d.delbene@gmail.com

ORCiD: https://orcid.org/0000-0002-7879-5275

\section{Raquel Neyra}

$\varangle$ raquelneyra@hotmail.com

ORCiD: https://orcid.org/0000-0001-5618-7511

\section{Lucrecia Wagner}

$\varangle$ lucrewagner@gmail.com

ORCiD: https://orcid.org/0000-0002-0848-5255

\section{Joan Martínez-Alier}

$\varangle$ joanmartinezalier@gmail.com

ORCiD: https://orcid.org/0000-0002-6124-539X

How to cite: SAES, B.M.; DEL BENE, D.; NEYRA, R.; WAGNER, L.; MARTINEZ-ALIER, J. Environmental justice and corporate social irresponsibility: the case of the mining company Vale S.A.. Ambiente \& Sociedade. São Paulo, v. 24, p. 1-23, 2021. 


\title{
Justiça ambiental e irresponsabilidade social corporativa: o caso da mineradora Vale S.A
}

\author{
Beatriz Macchione Saes \\ Daniela Del Bene \\ Raquel Neyra \\ Lucrecia Wagner \\ Joan Martínez-Alier
}

São Paulo. Vol. 24, 2021

Ideias em Debat Insurgências Decoloniais e Horizontes Emancipatórios:

Contribuições da Ecologia Política
Resumo: Após o rompimento da barragem de rejeitos da Vale em Brumadinho (Minas Gerais) no início de 2019, um conjunto de pesquisadores e ativistas de várias partes do mundo produziu um mapa temático no Atlas Global de Justiça Ambiental (EJAtlas) reunindo trinta casos de conflitos ambientais em que a mineradora teve um papel importante. No presente artigo, esses casos são analisados à luz dos discursos e práticas de Responsabilidade Social Corporativa (RSC) da Vale, visando explorar a contradição de elevados padrões de RSC na companhia e em outras grandes multinacionais do setor da mineração coexistirem com muitos conflitos socioambientais. A análise indica que a atuação da companhia contrasta com o seu discurso de RSC e que, mesmo quando considera sua atuação responsável e exemplar, a Vale reproduz injustiças ambientais e está, na verdade, praticando Irresponsabilidade Social Corporativa.

Palavras-chave: Justiça ambiental; irresponsabilidade social corporativa; mineração.

Como citar: SAES, B.M.; DEL BENE, D.; NEYRA, R.; WAGNER, L.; MARTINEZ-ALIER, J. Justiça ambiental e irresponsabilidade social corporativa: o caso da mineradora Vale S.A. Ambiente $\mathbb{\&}$ Sociedade. São Paulo, v. 24, p. 1-23, 2021. 


\title{
Justicia ambiental e irresponsabilidad social empresarial: el caso de la minera Vale S.A
}

\author{
Beatriz Macchione Saes \\ Daniela Del Bene \\ Raquel Neyra \\ Lucrecia Wagner \\ Joan Martínez-Alier
}

São Paulo. Vol. 24, 2021

Ideas en Debate

Insurgencias Deco-

loniales y Horizontes Emancipatórios:

Contribuiciones de la Ecología Politica
Resumen: Tras el colapso del dique de colas de Vale en Brumadinho (Minas Gerais) a inicios de 2019, un grupo de investigadores y activistas de diversas partes del mundo elaboró colectivamente un mapa temático en el Atlas Global de Justicia Ambiental (EJAtlas), reuniendo treinta casos de conflictos ambientales en los que la empresa minera tuvo un rol importante. En este artículo, esos casos son analizados a la luz de los discursos y prácticas de responsabilidad social empresaria (RSE) de Vale, con el fin de explorar la contradicción entre los elevados estándares de RSE de la empresa y de otras grandes multinacionales mineras, y la existencia de muchos conflictos socioambientales. El análisis indica que la actuación de la empresa contrasta con su discurso de RSE y que, incluso cuando considera que su desempeño es responsable y ejemplar, Vale reproduce injusticias ambientales y está, de hecho, practicando la Irresponsabilidad Social Empresarial..

Palabras-clave: La justicia ambiental; la irresponsabilidad social corporativa; la minería.

Como citar: SAES, B.M.; DEL BENE, D.; NEYRA, R.; WAGNER, L.; MARTINEZ-ALIER, J. Justicia ambiental e irresponsabilidad social empresarial: el caso de la minera Vale S.A. Ambiente $\&$ Sociedade. São Paulo, v. 24, p. 1-23, 2021.

DOI: http://dx.doi.org/10.1590/1809-4422asoc20210014vu2021L4ID 